\title{
Seasonal dynamics of butterfly population in DAE Campus, Kalpakkam, Tamil Nadu, India
}

\author{
K. Jahir Hussain ${ }^{1}$, T. Ramesh ${ }^{2}$, K.K. Satpathy ${ }^{3} \&$ M. Selvanayagam ${ }^{4}$ \\ ${ }^{1,3}$ Environmental and Safety Division, Radiological Safety \& Environmental Group, Indira Gandhi Centre for Atomic Research, \\ Kalpakkam, Tamil Nadu 603102, India \\ ${ }_{2,4}^{4}$ Loyola Institute of Frontier Energy (LIFE), Loyola College, Chennai, Tamil Nadu 600034, India \\ Email: ${ }^{1}$ zakir781@yahoo.co.in, ${ }^{2}$ faunaldiversity@gmail.com, ${ }^{3}$ satpathy@igcar.gov.in (corresponding author), ${ }^{4}$ drmssel@yahoo.co.in
}

Date of publication (online): 26 January 2011 Date of publication (print): 26 January 2011 ISSN 0974-7907 (online) | 0974-7893 (print)

Editor: K.A. Subramanian

\section{Manuscript details:}

Ms \# 02603

Received 14 October 2010

Final received 24 November 2010

Finally accepted 06 December 2010

Citation: Hussain, K.J., T. Ramesh, K.K. Satpathy \& M. Selvanayagam (2011). Seasonal dynamics of butterfly population in DAE Campus, Kalpakkam, Tamil Nadu, India. Journal of Threatened Taxa 3(1): 1401-1414.

Copyright: @ K. Jahir Hussain, T. Ramesh, K.K Satpathy \& M. Selvanayagam 2011. Creative Commons Attribution 3.0 Unported License. JoTT allows unrestricted use of this article in any medium for non-profit purposes, reproduction and distribution by providing adequate credit to the authors and the source of publication.

Author Details: see end of this article.

Author Contribution: TR helped KJH during the field work and in Manuscript preparation. KKS and MS immensely contributed in manuscript correction and in designing the investigation.

Acknowledgements: Authors are thankful to Dr. Krushnamegh Kunte, Harvard University, Cambridge, USA, for help in identification. Authors are grateful to Dr. Baldev Raj, Director, IGCAR for his continuous encouragement and support.

\begin{abstract}
Seasonal population trends of butterflies inhabiting the campus of Department of Atomic Energy (DAE) at Kalpakkam were recorded by setting a permanent line transect of $300 \mathrm{~m}$ and recording all species of butterflies observed within a $5 \mathrm{~m}$ distance. The survey yielded 2177 individuals of 56 butterfly species, belonging to the families Nymphalidae, Pieridae, Lycaenidae, Papilionidae and Hesperiidae. Nymphalidae were found to be the dominant family during all seasons. Species richness and abundance were highest during the northeast monsoon and winter periods, indicating that in the southern plains of India butterflies prefer cool seasons for breeding and emergence. The taxonomic structure of the butterflies sampled resembles that of the Western Ghats and other regions of India in two ways: (a) dominance of nymphalids and (b) peak abundance during wet seasons. A detailed study of ecologically important local butterfly fauna and their host plants is in progress, to construct a butterfly garden in Kalpakkam to attract and support butterflies.
\end{abstract}

Keywords: Butterfly, DAE campus, dominance, Kalpakkam, peak abundance, seasonality.

\section{INTRODUCTION}

Seasonality is a common phenomenon in insect populations. Seasonal fluctuations are often influenced by environmental factors including temperature, photoperiod, rainfall, humidity, variation in the availability of food resources, and vegetation cover such as herbs and shrubs (Anu 2006; Anu et al. 2009; Shanthi et al. 2009; Tiple \& Khurad 2009). Butterflies have important ecosystem roles including pollination, and they are useful in studies of population and community ecology (Pollard 1991) as indicators of ecosystem health because they are very sensitive to changes in microclimate and habitat (Erhardt 1985; Kremen 1992). Many species are strictly seasonal (Kunte 1997), and their population dynamics are generally considered to be governed by environmental factors. In India butterflies have been documented since the turn of $19^{\text {th }}$ century (Williams 1927, 1930, 1938), however, little information is available concerning butterflies in the southern plains region. The purpose of this study is to determine trends in butterfly species constellations and identify their

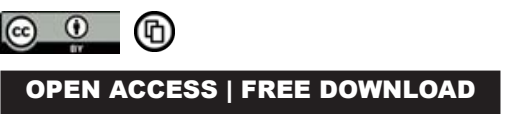

This article is part of the peer-reviewed Proceedings of the $3^{\text {rd }}$ Asian Lepidoptera Conservation Symposium (3ALCS-2010) jointly organized by the IUCN SSC South Asian Invertebrate Specialist Group (SAsISG); Department of Zoology, Bharathiar University; Zoo Outreach Organisation and Wildlife Information Liaison Development, held from 25 to 29 October 2010 at Coimbatore, Tamil Nadu, India. http://www.zooreach.org/3alcs2010.html 


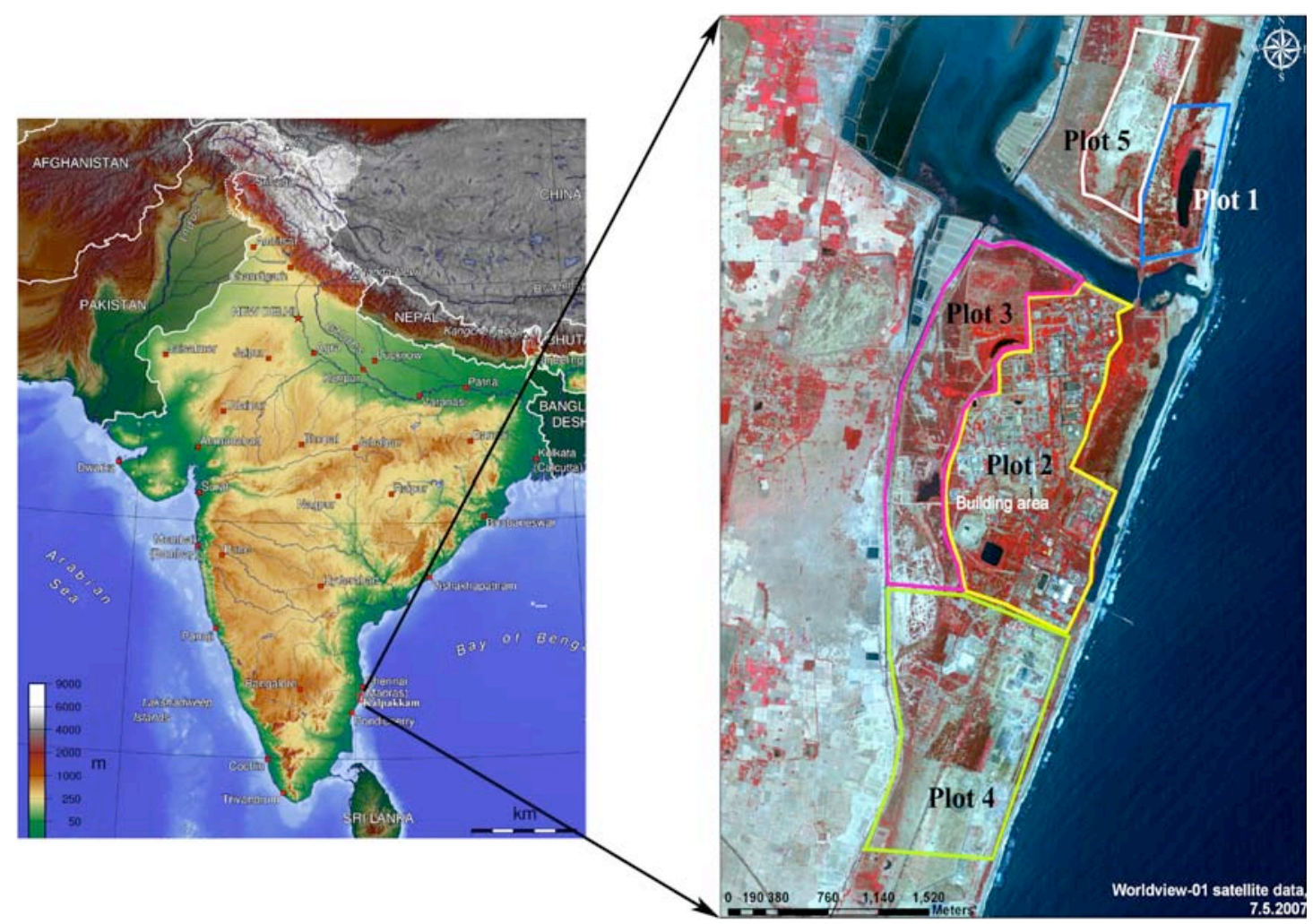

Image 1. Study area

temporal variation, diversity and abundance.

\section{MATERIALS AND METHODS}

Study area: The DAE campus at Kalpakkam (12 ${ }^{0} 33.7^{\prime} \mathrm{N} \& 80^{\circ} 10.5^{\prime} \mathrm{E}, \sim 2500$ acres), Tamil Nadu, encompasses seashore and a vast plain area of the Bay of Bengal (Image 1). The coastal system forms a complex natural site where intense interactions occur among land, sea and atmosphere. This unique ecosystem spreads through the biologically diverse and productive habitat of native flora and fauna and is aesthetically blended with introduced vegetation. The main natural vegetation observed at DAE campus is dry evergreen and scrub comprising of members predominantly belonging to the families Poaceae, Fabaceae, Cyperaceae, Asteraceae, Euphorbiaceae, Verbenaceae, Solanaceae, Rubiaceae, Convolvulaceae and Amaranthaceae (Gajendiran \& Ragupathy 2002).

Butterfly census technique: Butterfly species abundance was assessed quantitatively across different seasons. To determine abundance, field work was carried out from June 2008 to May 2009 using the line transect count method as per Kunte (1997) with minor modification. In this method five permanent 300-line transects were set up in each plot using Global Positioning System (GPS) (Garmin, 76CSx). Transects covered all microhabitats including gardens, scrub, riparian corridors, sandy areas and monoculture Casuarina plantation. Each transect was slowly traversed at a uniform pace for 30 minutes from 0930 to $1130 \mathrm{hr}$ during good weather periods (no heavy rain and strong wind). This is a suitable method adopted by others for surveying butterflies in a wide range of habitats (Walpole \& Sheldon 1999; Caldas \& Robbins 2003; Koh \& Sodhi 2004). All individuals were identified in the field using standard guides (Gunathilagaraj et al. 1998; Kunte 2000; Hussain et al. 2008).

Data analysis: For the interpretation of collected data, the year was divided into four periods: southwest monsoon - SWM (June to September), northeast monsoon - NEM (October to December), winter (January to February) and hot summer (March to May). Data on mean temperature, mean relative humidity, monthly rainfall and number of rainy days were collected from the meteorological station at IGCAR, 
Table 1. Total number, percentage of genus, species and individuals collected per family

\begin{tabular}{|c|l|c|c|c|}
\hline & Family & $\begin{array}{c}\text { No. of } \\
\text { genera }\end{array}$ & $\begin{array}{c}\text { No. of } \\
\text { species }\end{array}$ & $\begin{array}{c}\text { No. of } \\
\text { individual }\end{array}$ \\
\hline $\mathbf{1}$ & Papilionidae & $4(9 \%)$ & $5(9 \%)$ & $144(6.6 \%)$ \\
\hline $\mathbf{2}$ & Pieridae & $11(25 \%)$ & $15(26.7 \%)$ & $635(29 \%)$ \\
\hline $\mathbf{3}$ & Lycaenidae & $12(27.2 \%)$ & $12(21.4 \%)$ & $209(9.6 \%)$ \\
\hline $\mathbf{4}$ & Nymphalidae & $13(29.5 \%)$ & $20(35.7 \%)$ & $1176(54 \%)$ \\
\hline $\mathbf{5}$ & Hesperiidae & $4(9 \%)$ & $4(7 \%)$ & $13(0.5 \%)$ \\
\hline & Total $(5)$ & 44 & 56 & 2177 \\
\hline
\end{tabular}

Kalpakkam. Pearson's correlation analysis was carried out to assess correlations between abiotic factors and richness and abundance of the butterfly populations. Species richness (sample based rarefaction) at different seasons and seasonal species composition (cluster analysis) were calculated using Biodiversity Pro software version 2 (McAleece et al. 1997).

\section{RESULTS AND DISCUSSION}

Community composition of butterfly fauna: A total of 2177 individuals comprising 56 butterfly species from five families and 44 genera were recorded during the present study. Nymphalidae was the dominant family in terms of species richness (20 species; $29.5 \%$ of genera) and abundance, followed by Pieridae ( 15 species, $25 \%$ genera), Lycaenidae (12 species, $27.2 \%$ genera) and Papilionidae (five species, $9 \%$ genera). Hesperiidae was represented by only four species in the surveyed area (Table 1). A similar pattern has been reported from the northern and southern parts of the Western Ghats, and also from other regions of India (Kunte 1997; Devy \& Priya 2001; Sreekumar \& Balakrishnan 2001; Bhalodia et al. 2002; Chandra et al. 2002; Nair 2002; Soniya \& Palot 2002; Arun \& Azeez 2003; Palot \& Soniya 2003; Borkar \& Komarpant 2004; Rane \& Ranade 2004; Ambrose \& Raj 2005; Bhuyan et al. 2005; Eswaran \& Promod 2005; Padhye et al. 2006; Chandra et al. 2007; Chandrakar et al. 2007; Kumar et al. 2007; Rufus \& Sabarinathan 2007; Dolia et al. 2008). Interestingly, $62.5 \%$ of the species, and $83 \%$ of the individuals collected belonged to two families (Nymphalidae and Pieridae). The greatest number of species was observed in the month of October (32 species), representing 57\% of total species

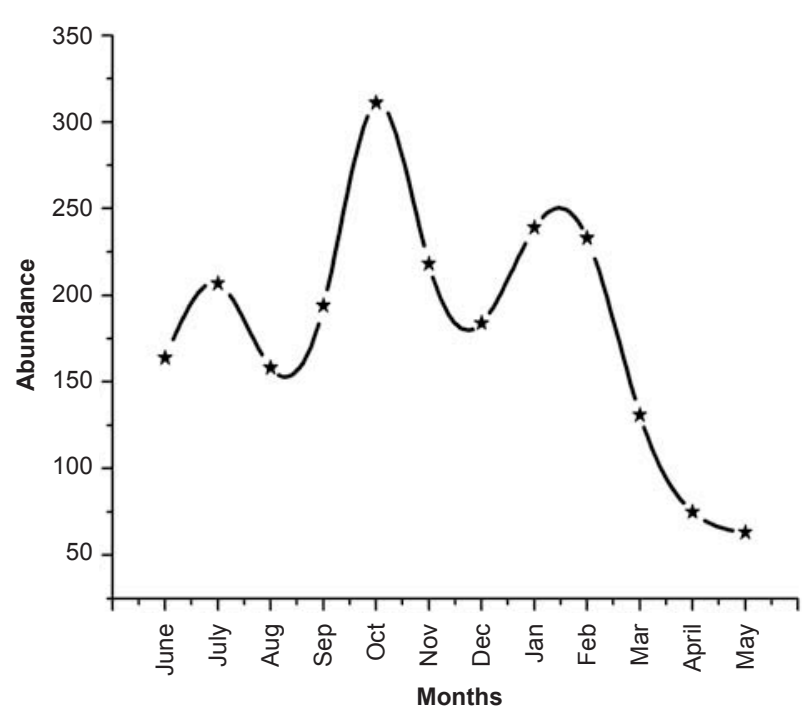

Figure 1. Abundance profile for butterflies observed in different months

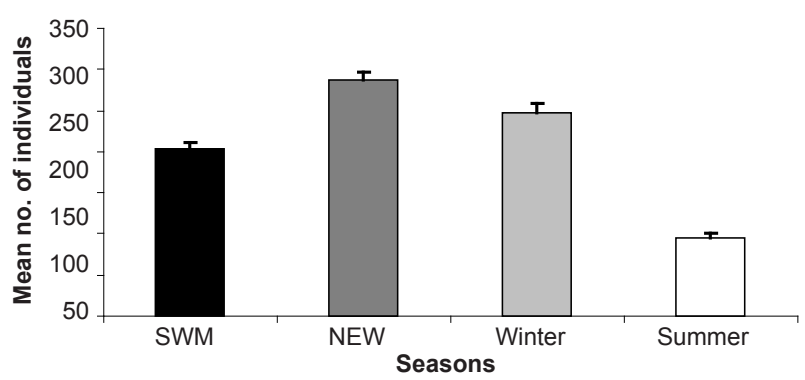

Figure 2. Seasonal abundance patterns of butterfly communities in Kalpakkam

( 8 species were represented by a single individual). Some species, namely, Danaus chrysippus, Acraea violae, Tirumala septentrionis, Eurema hecabe and Ariadne merione were observed regularly and more commonly (Appendix 1).

Temporal abundance and seasonality profile of butterflies: The observed butterfly numbers from all transects were pooled and considered as a

Table 2. Seasonality of butterflies in different seasons in Kalpakkam

\begin{tabular}{|l|c|c|c|c|}
\hline & SWM & NEM & Winter & Summer \\
\hline $\begin{array}{l}\text { Richness (number of } \\
\text { species) }\end{array}$ & 31 & 43 & 33 & 16 \\
\hline Abundance (Average) & 204 & 287 & 248 & 95 \\
\hline Unique species & 4 & 13 & 2 & - \\
\hline Rainfall (Mean $\mathrm{mm}$ ) & 224 & 744.5 & 18.5 & 35 \\
\hline $\begin{array}{l}\text { Temperature } \\
{ }^{\circ} \mathrm{C} \\
\text { (Average) }\end{array}$ & 30.6 & 28.4 & 27.7 & 31 \\
\hline
\end{tabular}




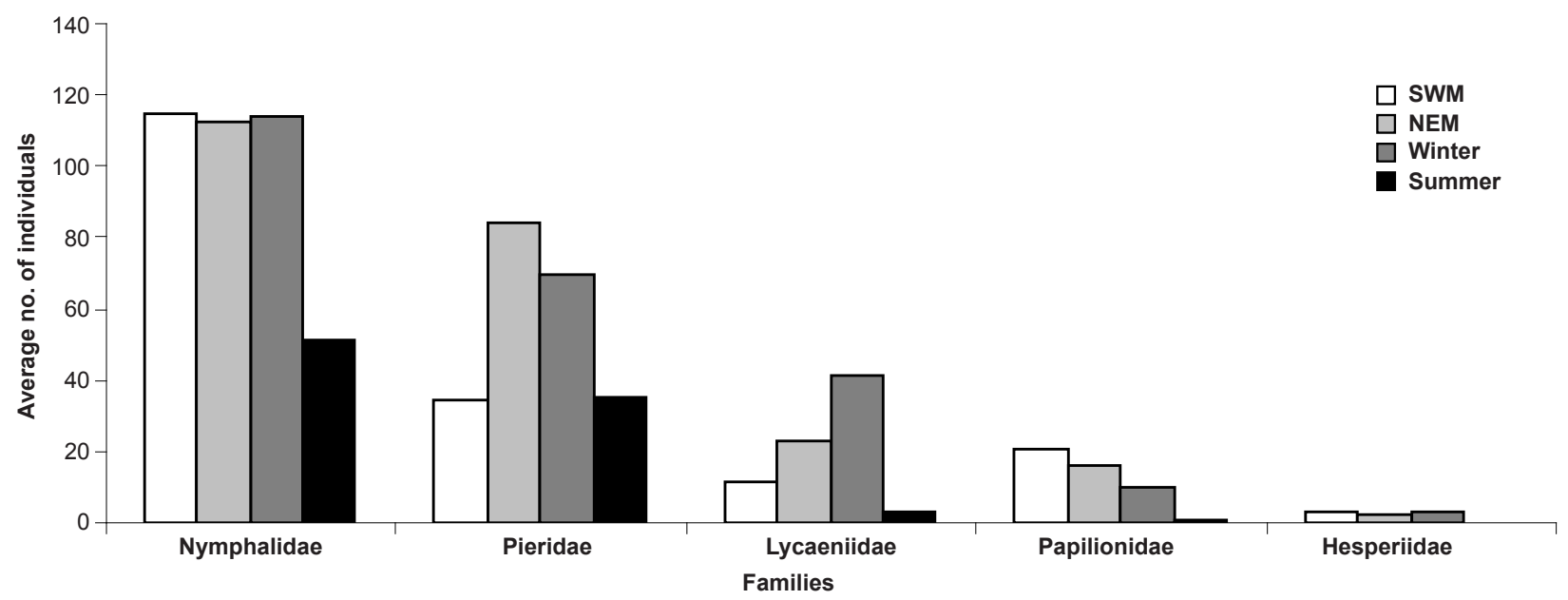

Figure 3. Population trends of butterfly families in different seasons

month of collection. Butterfly population fluctuated monthly. At DAE campus three major abundance peaks were observed in the months of July, October and January/February (Fig. 1). Earlier, Kunte (2005) had observed peak butterfly activity from October to January/February at Nilgiri and Anamalai Hills of southern Western Ghats. Our results are in accordance with his observation. Butterfly population rapidly declined during the period March to June. Usually, in southern India, these months are very hot (Maximum temperature $34^{\circ} \mathrm{C}$ ). Moreover, factors such as scarcity of water, poor nectar and dry vegetation, results in less butterfly abundance and lower survival ability of most species. Swaay (1990) suggests that butterflies, like any other insects are very vulnerable to changes in their environment because of their specialized life cycle. Any minor to major abiotic stress may lead to substantial decline to complete dwindling of the butterfly species and thus the change in butterfly diversity can be used as an indicator of environmental degradation.

Figure 2 describes butterfly abundance patterns during different seasons. More number of adult butterflies were observed during the periods of NEM and winter followed by SWM and summer. In southern plains, ideal breeding season for most of the butterflies is NEM and it continues till winter. This is due to the fact that during these seasons Tamil Nadu receives sufficient rain (Mean $744.5 \mathrm{~mm}$ ) and prevalence of conducive temperature $\left(28^{\circ} \mathrm{C}\right)$ (Table 2). These two factors are vital to both butterflies as well as larval host plants. In tropical region with distinct wet and dry seasons, many insect species attain maximum adult abundance during the wet seasons (Didham \& Springate 2003; Tiple \& Khurad 2009). In agreement with above observation, the present study also revealed that the butterfly abundance and species diversity were more during wet season (NEM) than in other periods. In India the monsoons govern, distribution of butterfly communities (Didham \& Springate 2003; Hill et al. 2003; Kunte 2005; Padhye et al. 2006; Tiple \& Khurad 2009) to a large extent. Many researchers have reported that butterflies are good responders to changes in the environment (Kunte 1997; Arun 2002; Borkar \& Komarpant 2004; Kunte 2005; Padhye et al. 2006; Tiple et al. 2006; 2007; Joshi 2007; Mathew \& Anto 2007; Krishnakumar et al. 2008). The relationships between butterflies and climate are complex, involving all four stages of the life cycle. Food habits among species (Gilbert \& Singer 1975; Kitahara et al. 2000) also influence the relationships between climate and butterfly diversity and abundance (South wood 1975). Some predominant host plants such as, Lantana camara, Lucas aspera, Tridax procumbens, Mimosa pudica, Gomphrena serrata, Vernonia cinerea, Tephrosia purpurea, Canthium dicoccum, Euphorbia antliquaram, Crotalaria verucosa, Heliotropium indicum, Calotropis gigantean have appeared to play major role on diversity and abundance patterns of butterfly communities at Kalpakkam. Some butterfly species were observed in more numbers and a few of them were seen at particular season. In our observation 13 unique species (seen only in single season) were recorded during NEM. Similarly four unique species 


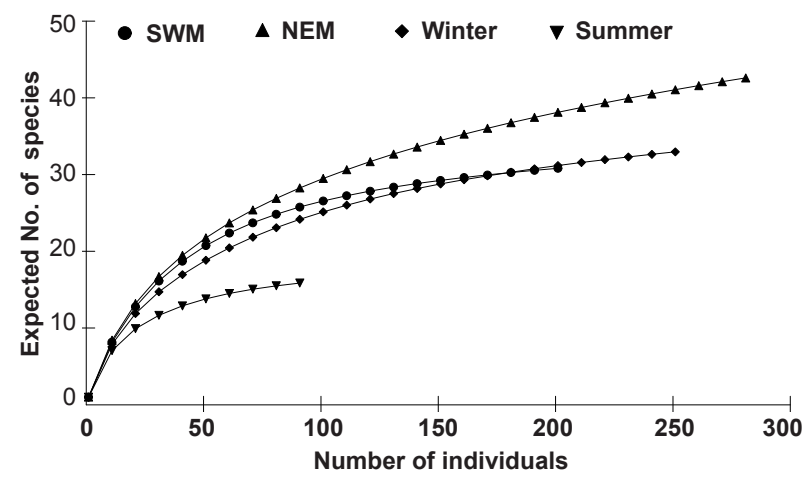

Figure 4. Sample based rarefaction curve for the different seasons

were observed in the SWM and only two unique species were observed during the winter (Table 2). This interesting pattern is not only due to the density/ availability of the host plants, but also probably due to the phenophases of the host plants (Kunte 2000-01).

Among overall family abundance, the Nymphalidae was preponderant during all the seasons, followed by Pieridae, Lycaenidae and Papilionidae. Abundance of Nymphalidae remained same during all seasons except during summer. On other hand, Pieridae and Lycaenidae populations fluctuated widely during all the seasons. Pieridae abundance was more during NEM, whereas Lycaenidae was more during winter. Seasonal preference of different groups could be the possible reasons and this gives rise to the emergence of unique species. Thus the presence of the unique species altered the entire population trend and changed
Jaccard cluster analysis (Single link)

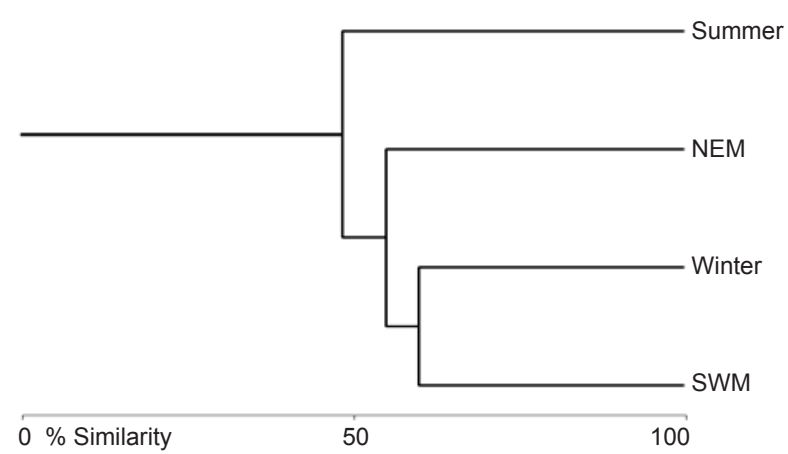

Figure 5. Jaccard similarity matrix dendrogram (presence and absence) comparing different seasons by their butterfly species assemblage

the community composition (Fig. 3).

Seasonal richness: Estimates of species richness during different seasons are expressed through sample based rarefaction (Fig. 4). Expected number of species have been plotted against occurrence of individuals. This plot provides a measure of species diversity which is robust to sample size effect permitting comparison between communities. Steep curves indicate more diverse communities. A striking point of an examination of the rarefaction curves is that during NEM period highest curvature was noticed indicating more diverse communities which also coincided with field observation. This means that species richness per occurrence of individuals was highest in this season. The other extreme season was summer during which relatively low species richness was observed.

Table 3. Abiotic and butterfly variation in different months

\begin{tabular}{|c|c|c|c|c|c|c|}
\hline Year-Month & $\begin{array}{l}\text { Temperature } \\
\text { ('C) }\end{array}$ & $\begin{array}{l}\text { Humidity } \\
(\%)\end{array}$ & Rainfall (mm) & Rainy days & Richness & Abundance \\
\hline 2008-June & $32.7(30.5)^{*}$ & $53.7(73.1)^{*}$ & 12.5 & 3 & 21 & 164 \\
\hline 2008-July & $31.2(30.7)^{*}$ & $65.5(73.5)$ * & 43 & 7 & 28 & 207 \\
\hline 2008-August & $30.0(29.3)$ * & $72.9(75.8)$ * & 104.5 & 11 & 24 & 158 \\
\hline 2008-September & $28.9(29.3)$ * & $73.9(79.8)$ * & 64 & 9 & 19 & 194 \\
\hline 2008-October & $28.8(28.2)$ * & $75.0(83.8)$ * & 307 & 16 & 32 & 311 \\
\hline 2008-November & $28.6(26.5)^{*}$ & $71.9(83.7)^{*}$ & 349 & 16 & 24 & 218 \\
\hline 2008-December & $28.0(26.3)$ * & $67.5(80.9)$ * & 88.5 & 2 & 26 & 184 \\
\hline 2009-January & $27.3(27.3)$ * & $65.9(80.0)$ * & 18.5 & 5 & 29 & 239 \\
\hline 2009-February & $28.2(27.4)$ * & $65.2(79.8)$ * & Nil & 0 & 25 & 233 \\
\hline 2009-March & $29.1(27.9)$ * & $71.4(81.7)^{*}$ & 13 & 2 & 16 & 131 \\
\hline 2009-April & $31.4(31.2)$ * & $68.6(81.9)$ * & Nil & 0 & 13 & 75 \\
\hline 2009-May & $32.6(30.6)$ * & $65.5(77.4)$ * & 22 & 3 & 11 & 63 \\
\hline
\end{tabular}

*Data in parenthesis is mean of 10 years (source: Kalpakkam Meteorological Station) 
Table 4. Correlation between weather parameter and butterfly population in DAE Campus, Kalpakkam

\begin{tabular}{|l|l|l|l|l|l|l|}
\hline Factors & Temp. $\left({ }^{\circ} \mathrm{C}\right)$ & Humidity & Rainfall $(\mathrm{mm})$ & Rainy day & Richness & Abundance \\
\hline Temp. $\left({ }^{\circ} \mathbf{C}\right)$ & 1 & & & & & \\
\hline Humidity & -0.506 & 1 & & & & \\
\hline Rainfall (mm) & -0.316 & 0.524 & 1 & & & \\
\hline Rainy day & -0.237 & $0.561^{*}$ & $0.889^{* *}$ & 1 & & \\
\hline Richness & $-0.578^{*}$ & 0.111 & 0.454 & 0.489 & 1 & \\
\hline Abundance & $-0.652^{*}$ & 0.225 & 0.547 & $0.566^{*}$ & $0.918^{* *}$ & 1 \\
\hline
\end{tabular}

* significant at $<0.05$; ${ }^{* *}$ significant at $<0.01$

SWM period appeared to have comparatively steeper rarefaction curve, indicating relatively high evenness as compared with most other communities, whereas winter has relatively low evenness.

Cluster analysis: The clustering of species based on their presence and absence during different seasonal periods was compared by using Jaccard single linkage clustering (Fig. 5). The similarity matrix showed that SWM and winter formed a single cluster group. This indicated that both periods having the similar species composition, while NEM and summer periods behaved as independent period. Eventhough the above finding conforms the seasonal variability in species composition, the scale of variability was just $10-15 \%$, which is not significant. This clearly showed that entire butterfly community was made up of large proportion of common species of general nature.

Abundance, richness and their correlation with weather parameters: Butterflies prefer a suitable climatic condition and they respond reasonably to even subtle the change in climate, which has been attributed to the fact that their entire life directly depend on temperature and monsoons. Mathew \& Anto (2007) have reported that temperature ranges between 27 $29{ }^{\circ} \mathrm{C}$ and humidity ranging between $60-80 \%$ are the most favourable for butterfly growth. In present study, the period between September to February (NEM and winter) was found to be conducive for butterfly community, which was mainly due to the optimum temperature and high humidity. Earlier studies (Kunte 2000-01; Padhye et al. 2006; Tiple \& Khurad 2009) also suggest that temperature and precipitation are two vital factors which influence butterflies richness and population directly. Their abundance and richness increased with decreasing temperature and increasing humidity, the abundance drastically decreased at higher temperature during summer months which ranged from March to May (Tables $2 \& 3$ ).

Increase in temperature during summer and increase in relative humidity during rainy seasons significantly influenced the population buildup and communities at Kalpakkam. Similar findings have been reported from elsewhere where in the population was correlated negatively with temperature and positively with relative humidity (Mathew \& Anto 2007).

The correlation analysis between weather parameter and butterfly diversity and abundance at Kalpakkam is given in Table 4. During the present study increased number of butterfly species was associated with wetter seasons, and their abundance fluctuation was positively correlated with richness $(\mathrm{R}=0.918, \mathrm{p}=$ $<0.01 \%$ ) (Woods et al. 2008; Tiple \& Khurad 2009). Temperature was negatively correlated with richness $(\mathrm{R}=-0.578, \mathrm{p}=<0.05)$ and abundance $(\mathrm{R}=-0.652$, $\mathrm{p}=<0.05$ ). It is known fact that high temperature negatively affects butterfly abundance, life cycle and activity (Roy et al. 2001). It is known that elevated atmospheric temperature affects adversely the butterfly abundance, life cycle and their psychological activity (Roy et al. 2001). In the present investigation the Plain Tiger and Tawny Castor were observed during all the seasons and significant numbers were observed even during summer. In this context it is worth mentioning that species present during summer and presumed to be well adapted species are hardly the ones well adapted to other seasons.

\section{CONCLUSION}

Nymphalidae was found to be the dominant family during all seasons, and October and January appeared to be the most favourable period for butterflies in the DAE campus. Moreover, the NEM periods followed 
Appendix 1. Seasonal abundance (mean) and list of butterfly species recorded in Kalpakkam

\begin{tabular}{|c|c|c|c|c|c|c|c|}
\hline & $\begin{array}{l}\text { Family I } \\
\text { Subfamily }\end{array}$ & Scientific name & Common name & SWM & NEM & Winter & Summer \\
\hline & Papilionidae & & & & & & \\
\hline 1 & Papilioninae & Atrophaneura aristolochiae (Fabricius, 1775) & Common Rose & 5 & & 2 & \\
\hline 2 & Papilioninae & Graphium agamemnon (Linnaeus, 1758) & Tailed Jay (Image 2) & & 1 & 1 & \\
\hline 3 & Papilioninae & Papilio polytes (Linnaeus, 1758) & Common Mormon & 2 & 2 & 3 & 1 \\
\hline 4 & Papilioninae & Pachliopta hector (Linnaeus, 1758) & Crimson Rose & 9 & 13 & 5 & \\
\hline \multirow[t]{2}{*}{5} & Papilioninae & Papilio demoleus (Linnaeus, 1758) & Lime Butterfly (Image 3) & 5 & 2 & & \\
\hline & Pieridae & & & & & & \\
\hline 6 & Coliadinae & Catopsilia pyranthe (Linnaeus, 1758) & Mottled Emigrant & & 41 & 1 & \\
\hline 7 & Coliadinae & Catopsilia Pomona (Fabricius, 1775) & Common Emigrant & 6 & 18 & 1 & 2 \\
\hline 8 & Coliadinae & Eurema hecabe (Linnaeus, 1758) & $\begin{array}{l}\text { Common Grass Yellow } \\
\text { (Image 4) }\end{array}$ & 11 & 12 & 29 & 7 \\
\hline 9 & Pierinae & Anaphaeis aurota (Fabricius, 1793) & Pioneer (Image 5) & 13 & 9 & 11 & 9 \\
\hline 10 & Pierinae & Appias libythea Fabricius, 1775 & Striped Albatross & 1 & 2 & 2 & \\
\hline 11 & Pierinae & Cepora nerissa (Fabricius, 1795) & Common Gull & 5 & 6 & & \\
\hline 12 & Pierinae & Colotis amata (Fabricius, 1775) & Small Salmon Arab & 4 & 2 & 4 & 2 \\
\hline 13 & Pierinae & Colotis danae (Fabricius, 1775) & Crimson Tip (Image 6) & & 5 & & \\
\hline 14 & Pierinae & Colotis etrida (Boisduval, 1836) & Little Orange Tip & & & 1 & \\
\hline 15 & Pierinae & Colotis eucharis (Fabricius, 1775) & Plain Orange Tip & & 1 & & \\
\hline 16 & Pierinae & Delias eucharis (Drury, 1773) & Common Jezebel & & 3 & & \\
\hline 17 & Pierinae & Hebomoia glaucippe (Linnaeus, 1758) & Great Orange Tip & & 3 & & \\
\hline 18 & Pierinae & Pareronia valeria (Cramer, 1776) & Common Wanderer & & 3 & 5 & 3 \\
\hline 19 & Pierinae & Leptosia nina (Fabricius, 1793) & Psyche (Image 7) & 3 & 5 & 20 & 13 \\
\hline \multirow[t]{2}{*}{20} & Pierinae & Ixias pyrene (Linnaeus, 1764) & Yellow Orange Tip & & 1 & & \\
\hline & Nymphalidae & & & & & & \\
\hline 21 & Biblidinae & Ariadne merione (Cramer, 1777) & Common Castor (Image 8) & 5 & 15 & 16 & 9 \\
\hline 22 & Danainae & Danaus chrysippus (Linnaeus, 1758) & Plain Tiger (Image 9) & 42 & 39 & 33 & 19 \\
\hline 23 & Danainae & Danaus genutia (Cramer, 1779) & Striped Tiger (Image 10) & 4 & 1 & 8 & 1 \\
\hline 24 & Danainae & Euploea core (Cramer, 1780) & Common Crow (Image 11) & 7 & 4 & 4 & 4 \\
\hline 25 & Danainae & Tirumala limniace (Cramer, 1775) & Blue Tiger (Image 12) & 8 & 9 & 3 & \\
\hline 26 & Danainae & Tirumala septentrionis (Butler, 1874) & Dark Blue Tiger & 16 & 15 & 5 & 4 \\
\hline 27 & Heliconiinae & Acraea violae(Fabricius, 1793) & Tawny Coster & 21 & 20 & 36 & 14 \\
\hline 28 & Heliconiinae & Phalanta phalantha (Drury, 1773) & Common Leopard & 5 & 5 & 2 & \\
\hline 29 & Limenitidinae & Neptis hylas (Linnaeus, 1758) & Common Sailer (Image 13) & 1 & 1 & 4 & 3 \\
\hline 30 & Nymphalinae & Hypolimnas bolina (Linnaeus, 1758) & Great Eggfly (Image 14) & & 4 & & \\
\hline 31 & Nymphalinae & Hypolimnas misippus (Linnaeus, 1764) & Danaid Eggfly & & 4 & 1 & \\
\hline 32 & Nymphalinae & Junonia orithya (Linnaeus, 1764) & Blue Pansy & 2 & & 1 & \\
\hline 33 & Nymphalinae & Junonia iphita (Cramer, 1779) & $\begin{array}{l}\text { Chocolate Pansy } \\
\text { (Image 15) }\end{array}$ & & 2 & 1 & \\
\hline 34 & Nymphalinae & Junonia atlites (Linnaeus, 1763) & Grey Pansy (Image 16) & 5 & & & \\
\hline 35 & Nymphalinae & Junonia lemonias (Linnaeus, 1758) & Lemon Pansy (Image 17) & 6 & 1 & 2 & 1 \\
\hline 36 & Nymphalinae & Junonia almana (Linnaeus, 1758) & Peacock Pansy (Image 18) & 1 & & 3 & \\
\hline 37 & Nymphalinae & Junonia hierta (Fabricius, 1798) & Yellow Pansy (Image 19) & & 1 & & \\
\hline 38 & Nymphalinae & Cynthia cardui (Linnaeus, 1758) & Painted Lady (Image 20) & 2 & & & \\
\hline 39 & Satyrinae & Melanitis leda (Linnaeus, 1758) & Common Evening Brown & 1 & & & \\
\hline 40 & Satyrinae & Mycalesis perseus (Fabricius, 1775) & Common Bush Brown & & 1 & & \\
\hline
\end{tabular}




\begin{tabular}{|c|c|c|c|c|c|c|c|}
\hline & $\begin{array}{l}\text { Family I } \\
\text { Subfamily }\end{array}$ & Scientific name & Common name & SWM & NEM & Winter & Summer \\
\hline & Lycaenidae & & & & & & \\
\hline 41 & Curetinae & Curetis thetis (Drury, 1773) & Indian Sunbeam & & 3 & & \\
\hline 42 & Polyommatinae & Azanus ubaldus (Cramer, 1782) & Bright Babul Blue & 2 & & & \\
\hline 43 & Polyommatinae & Castalius rosimon (Fabricius, 1775) & Common Pierrot (Image 21) & 9 & 12 & 26 & 3 \\
\hline 44 & Polyommatinae & Catochrysops strabo (Fabricius, 1793) & ${ }^{*}$ Forget Me Not & & & & \\
\hline 45 & Polyommatinae & Chilades lajus (Stoll, 1780) & Lime Blue & & 4 & & \\
\hline 46 & Polyommatinae & Everes lacturnus (Godart, 1824) & Indian Cupid & 3 & 1 & 1 & \\
\hline 47 & Polyommatinae & Jamidesceleno celeno (Cramer, 1775) & Common Cerulean & & & 7 & \\
\hline 48 & Polyommatinae & Leptotes plinius (Fabricius, 1793) & Zebra Blue & 1 & & 5 & \\
\hline 49 & Polyommatinae & Pseudozizeeria maha (Kollar, 1844) & Pale Grass Blue & & 13 & 6 & \\
\hline 50 & Polyommatinae & Zizina otis (Fabricius, 1787) & * Lesser Grass Blue & & & & \\
\hline 51 & Theclinae & Arhopala amantes (Hewitson, 1862) & * Large Oakblue & & & & \\
\hline \multirow[t]{2}{*}{52} & Theclinae & Spindasis vulcanus (Fabricius, 1775) & Common Silverline & & 1 & & \\
\hline & Hesperiidae & & & & & & \\
\hline 53 & Hesperiinae & Parnara guttata (Bremer \& Grey, 1852) & Common Straight Swift & 3 & 2 & 3 & \\
\hline 54 & Hesperiinae & Suastus gremius (Fabricius, 1798) & * Indian Palm Bob & & & & \\
\hline 55 & Pyrginae & Gomalia elma (Trimen, 1862) & *African Mallow Skipper & & & & \\
\hline \multirow[t]{2}{*}{56} & Pyrginae & Spialia galba (Fabricius, 1793) & Indian Grizzled Skipper & & 1 & & \\
\hline & & & Total (56 Species) & 204 & 287 & 248 & 95 \\
\hline
\end{tabular}

*recorded only during inventory, hence, not included in data

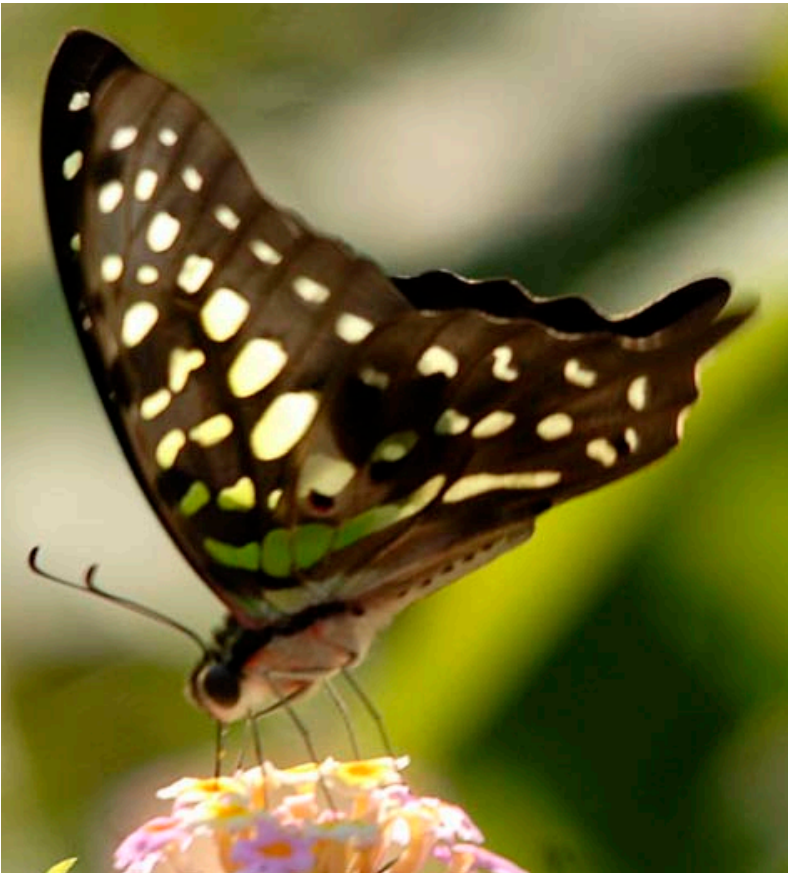

Image 2. Tailed Jay Graphium agamemnon

by winter are more diverse and denser seasons for these insects. From cluster analysis it was clear that the overall species assemblage variability was very

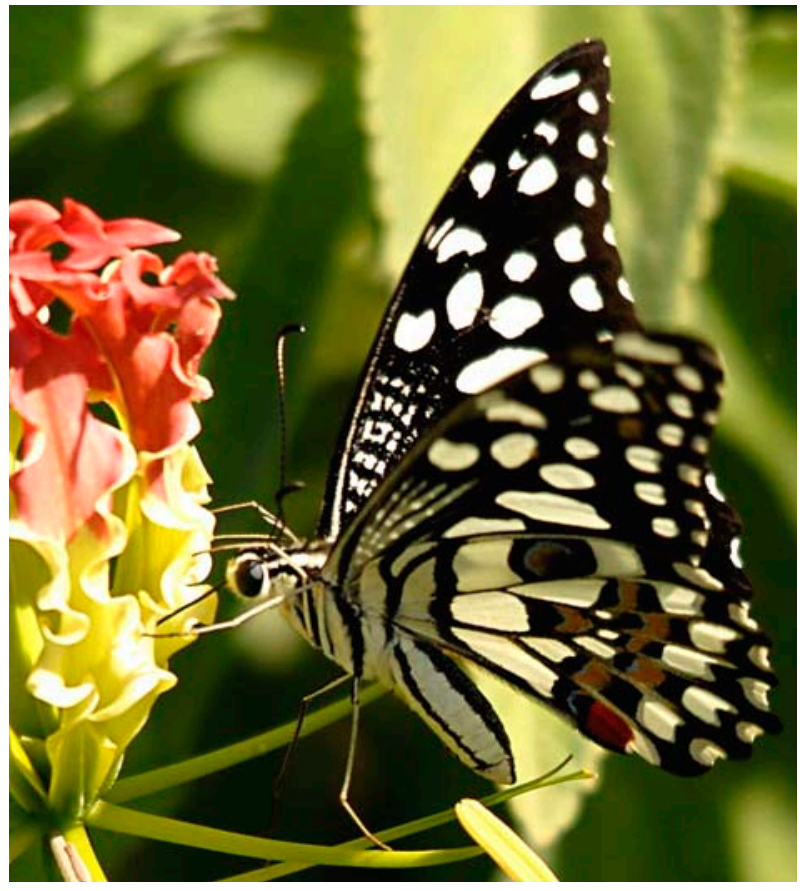

Image 3. Lime Butterfly Papilio demoleus

meager. This was due to the dominance of generalist species rather than seasonal specialists. It was also observed that NEM harboured more seasonal specialist 

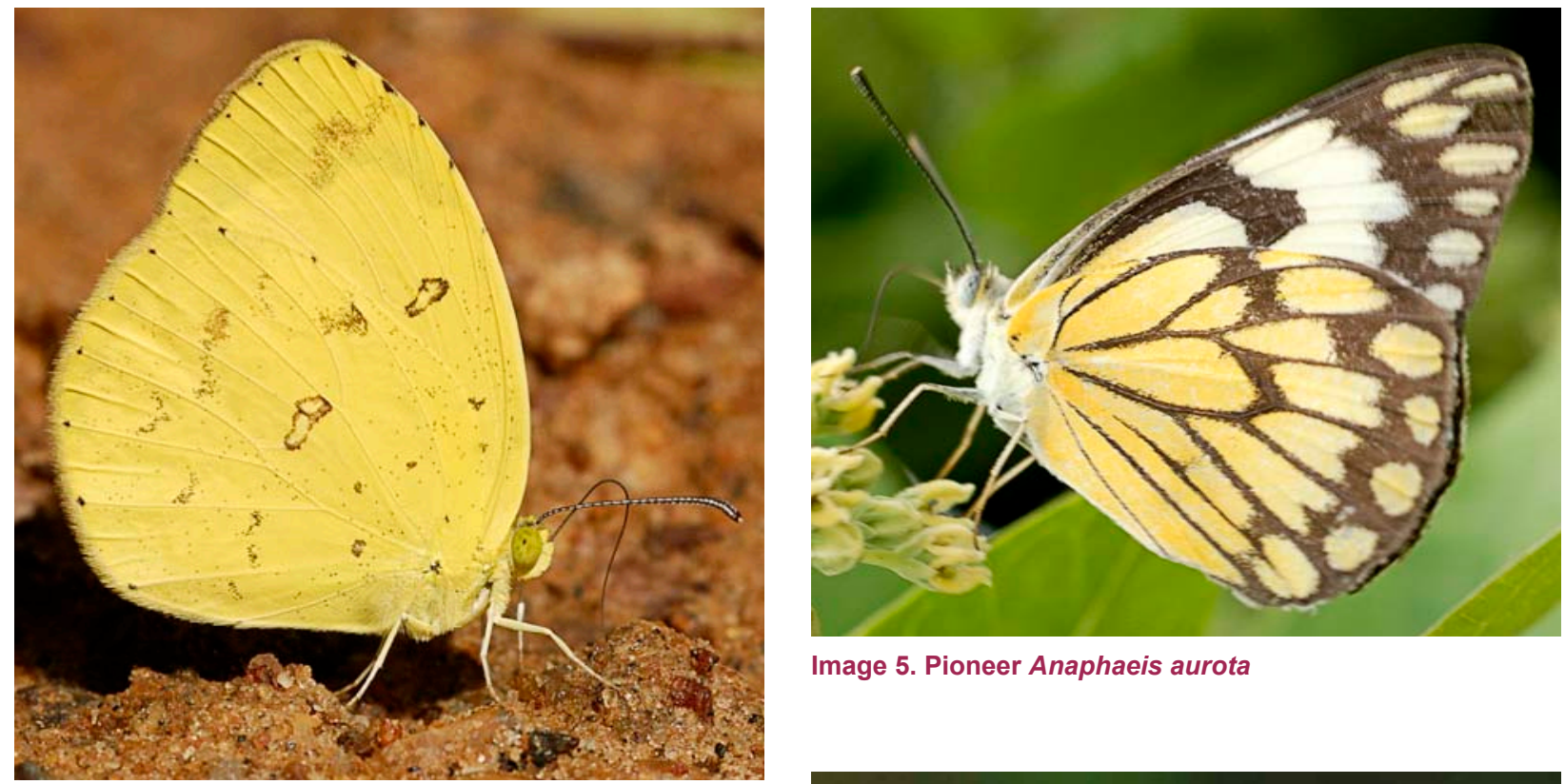

Image 5. Pioneer Anaphaeis aurota

Image 4. Common Grass Yellow Eurema hecabe
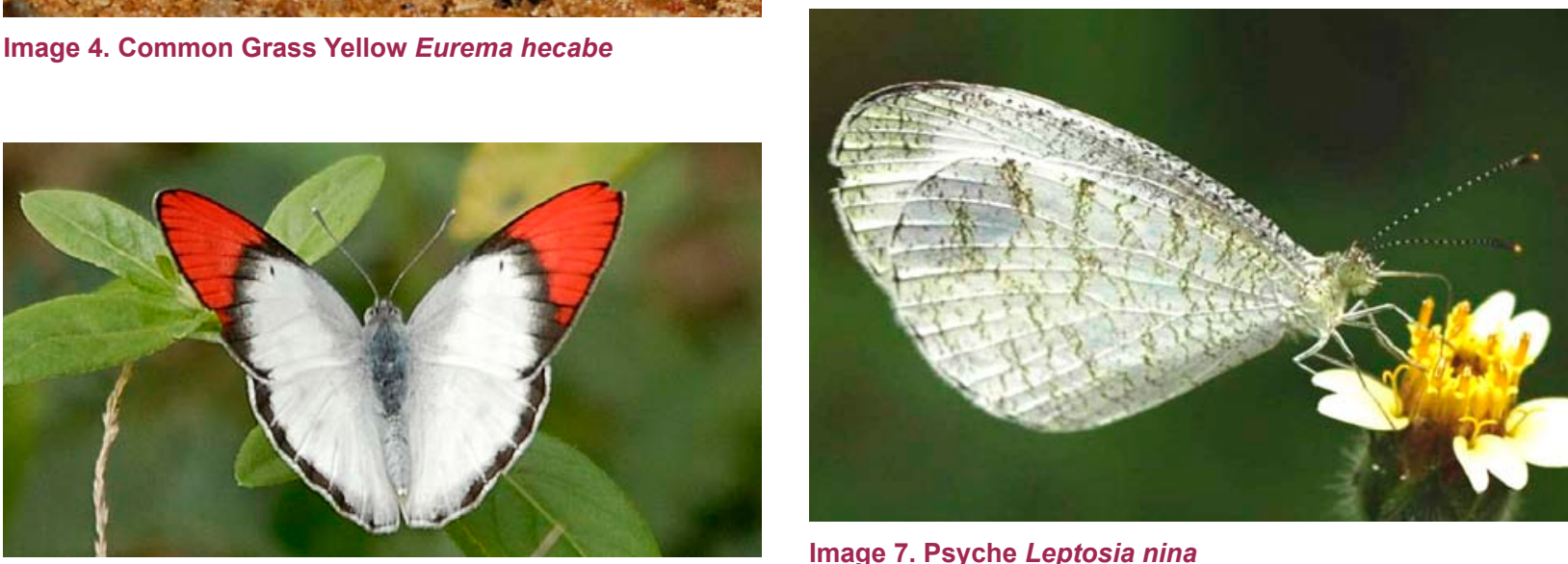

Image 6. Crimson Tip Colotis danae

Image 7. Psyche Leptosia nina
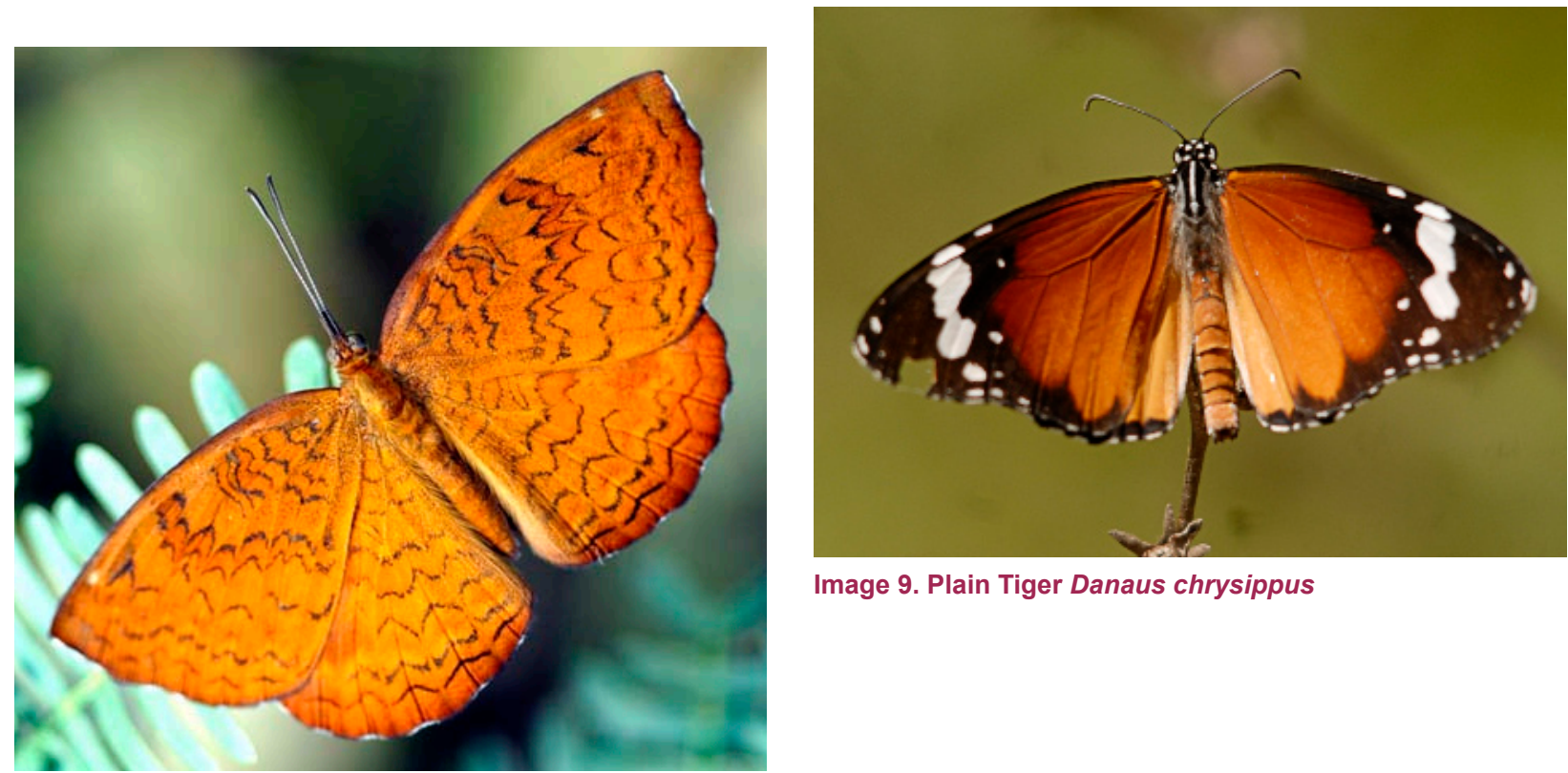

Image 9. Plain Tiger Danaus chrysippus

Image 8. Common Castor Ariadne merione

Journal of Threatened Taxa | www.threatenedtaxa.org | January 2011 | 3(1): 1401-1414 


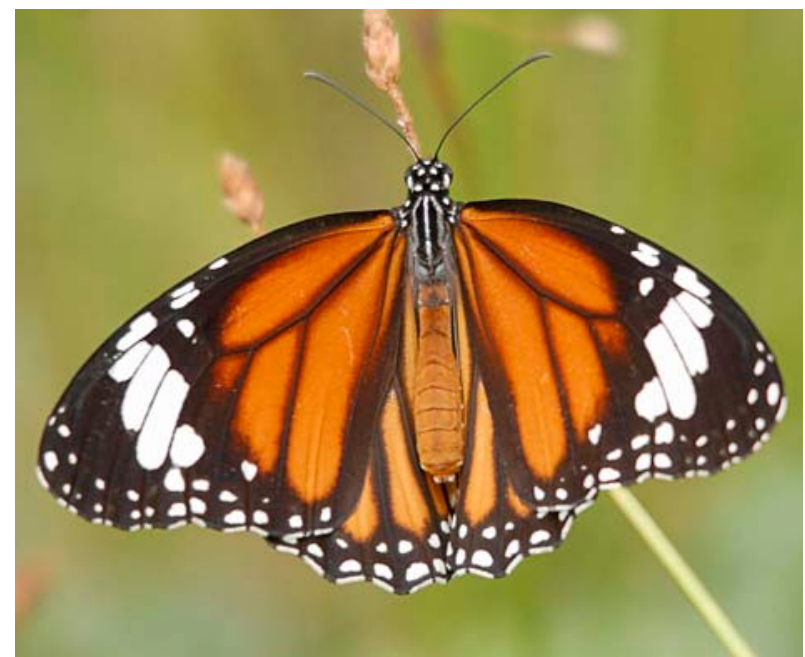

Image 10. Striped Tiger Danaus genutia

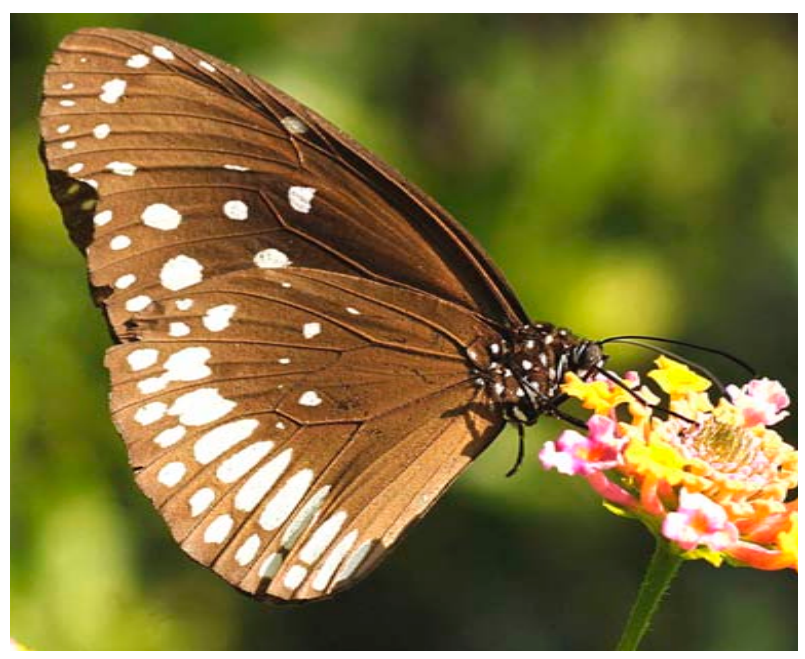

Image 11. Common Crow Euploea core

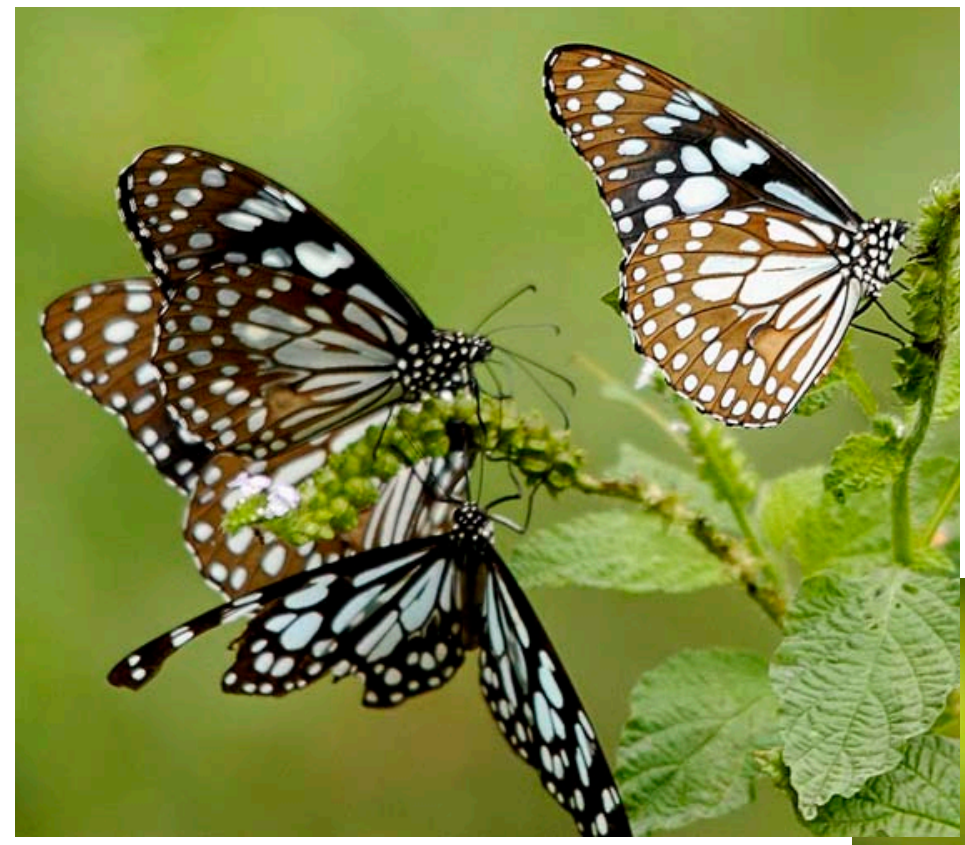

Image 12. Blue Tiger Tirumala limniace

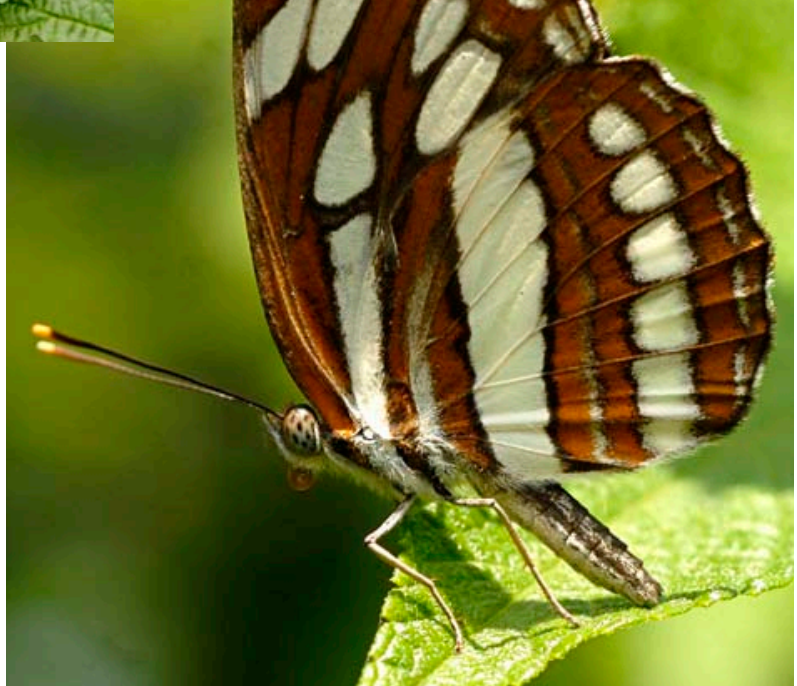

Image 13. Common Sailer Neptis hylas 


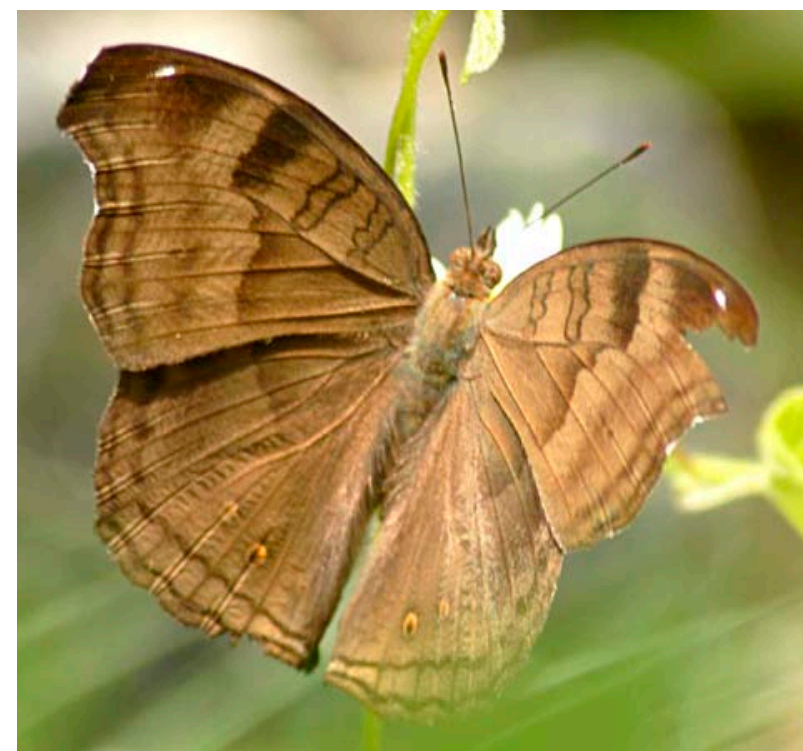

Image 15. Choclate Pansy Junonia iphita

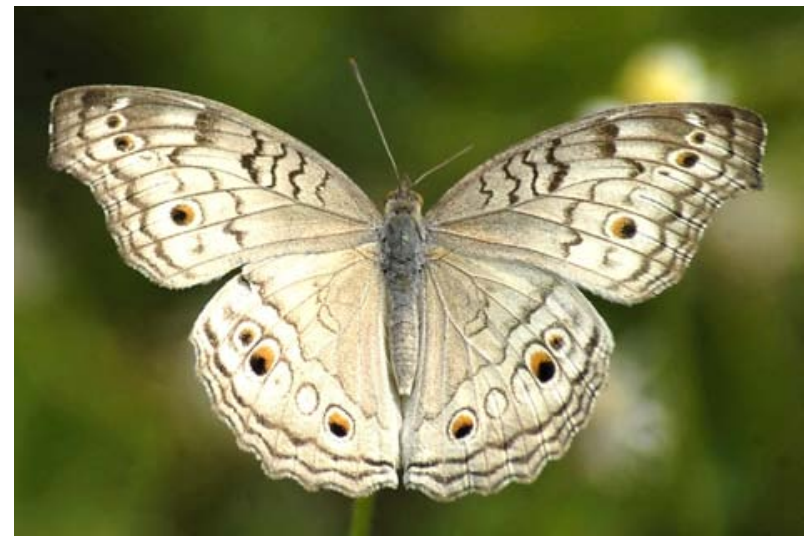

Image 16. Grey Pansy Junonia atlites

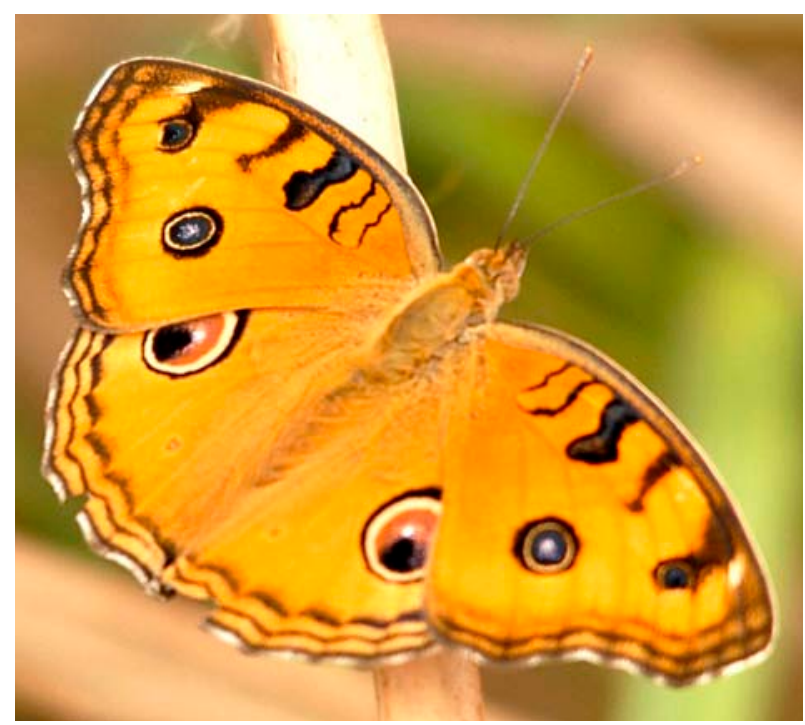

Image 18. Peacock Pansy Junonia almana

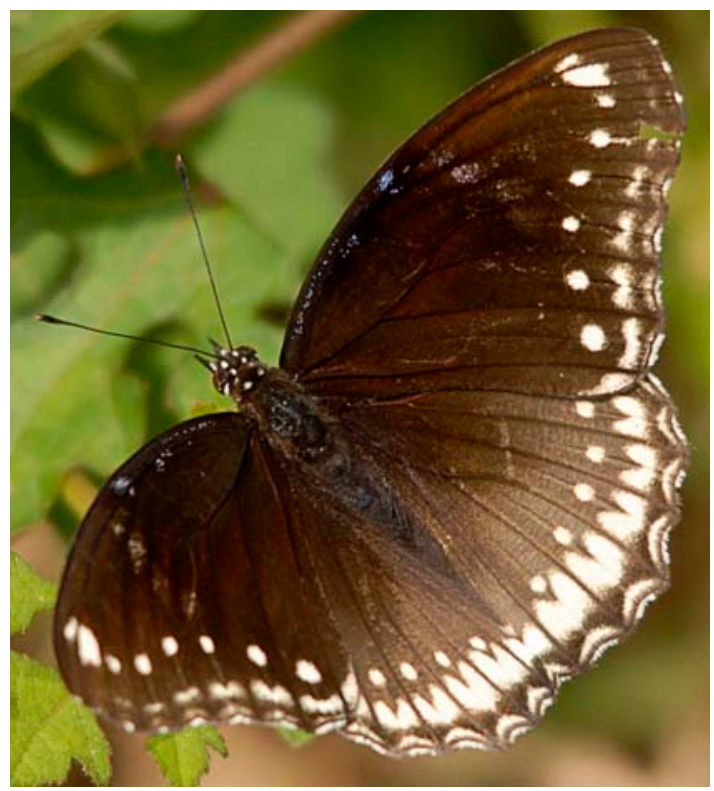

Image 14. Great Eggfly Hypolimnas bolina

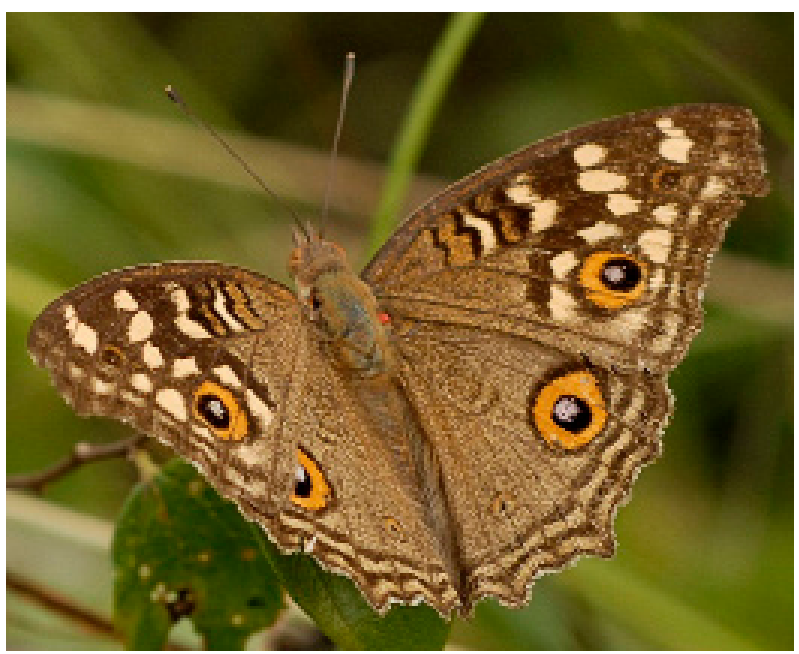

Image 17. Lemon Pansy Junonia hierta

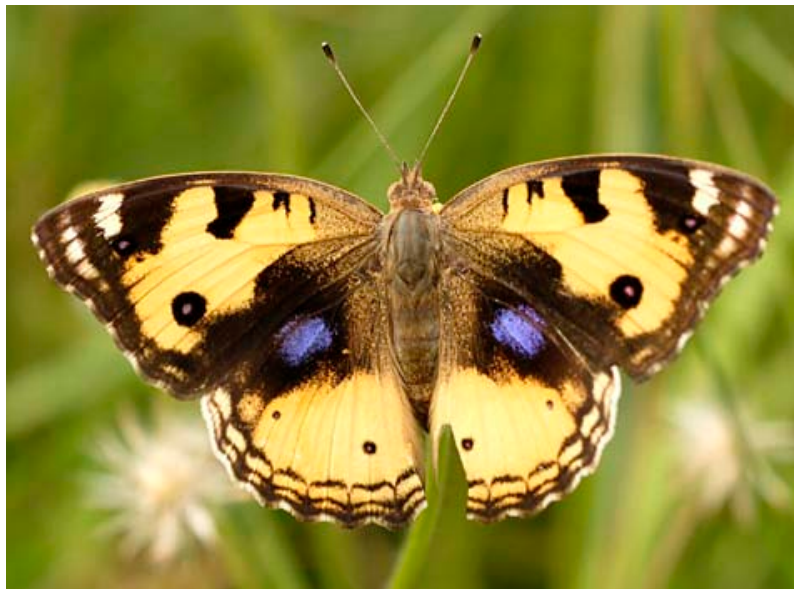

Image 19. Yellow Pansy Junonia hierta

Journal of Threatened Taxa | www.threatenedtaxa.org | January 2011 | 3(1): 1401-1414 


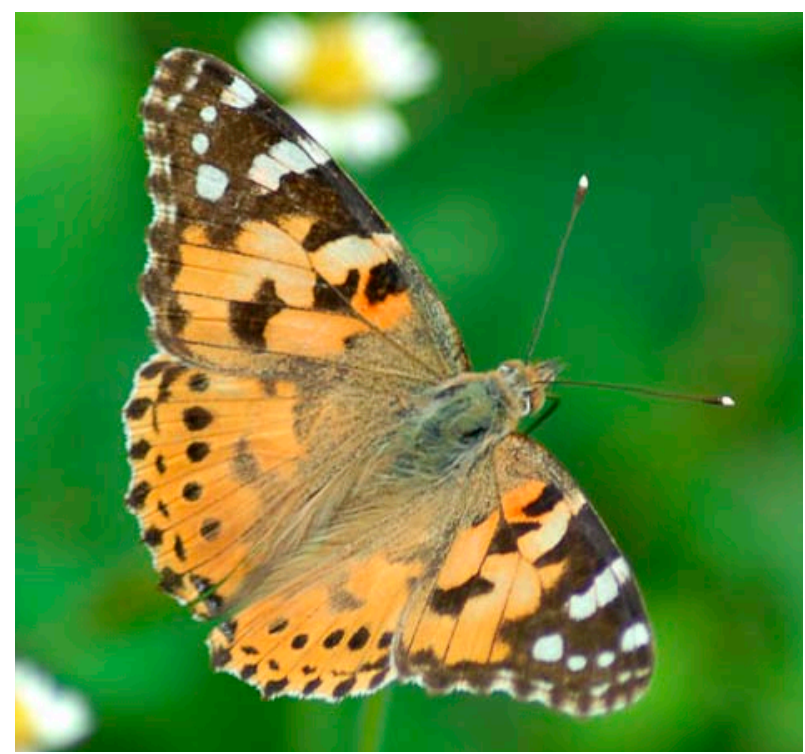

Image 20. Painted Lady Cynthia cardui

species than other seasons. In the present study we observed that the temperature range of $27-29{ }^{\circ} \mathrm{C}$ and relative humidity between $80-85 \%$ were most suitable climatic conditions for the coastal plain butterfly assemblage.

\section{REFERENCES}

Anu, A., T.K. Sabu \& P.J. Vineesh (2009). Seasonality of litter insects and relationship with rainfall in a wet evergreen forest in south Western Ghats. Journal of Insect Science 9: 46. available online: insectscience.org/9.46

Ambrose, D.P. \& D.S. Raj (2005). Butterflies of KalakadMundanthurai Tiger Reserve, Tamil Nadu. Zoos' Print Journal 20(12): 2100-2107.

Anu, A. (2006). Entomofaunal Dynamics and Biochemistry of Litter Decomposition in a Natural Forest with Special Reference to the Systematics of Dung Beetles (Coleoptera: Scarabaeinae). PhD Dissertation. University of Calicut, Kerala, India.

Arun, P.B. \& P.A. Azeez (2003). On the butterflies of Puyankutty forest, Kerala, India. Zoos' Print Journal 18(12): 1276-1279.

Arun, P.R. (2002). Butterflies of Siruvani forest of Western Ghats, with notes on their seasonality. Zoos' Print Journal 18(2): 1003-1006.

Bhalodia, K., V.J. Bhuva, S.M. Dave \& V.C. Soni (2002). Butterflies of Vansda national park, Gujarat. Zoos' Print Journal 17(10): 903-904.

Bhuyan, M., R.P. Bhattacharyya \& P.B. Kanjilal (2005). Butterflies of the Regional Reserch Laboratory Campus, Jorhat, Assam. Zoos' Print Journal 20(6): 1910-1911.

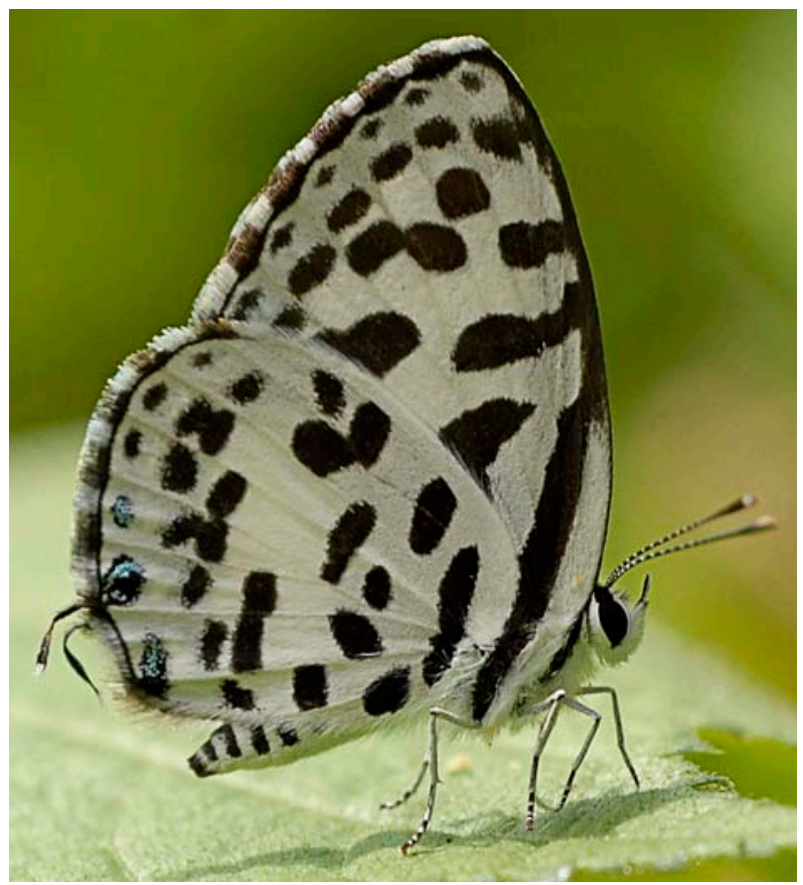

Image 21. Common Pierrot Castalius rosimon

Borkar, M.R. \& N. Komarpant (2004). Diversity, abundance and habitat associations of butterfly species in Bondla Wildlife Sanctuary of Goa, India. Zoos' Print Journal 19(10): 1648- 1653.

Caldas, A. \& R.K. Robbins (2003). Modified Pollard transects for assessing tropical butterfly abundance and diversity. Biological Conservation 110: 211-219.

Chandra, K., L.K. Chaudhary, R.K. Singh \& M.L. Koshta (2002). Butterflies of Pench Tiger Reserve, Madhya Pradesh. Zoos' Print Journal 17(10): 908-909.

Chandra, K., R.M. Sharma, A. Singh \& R.K. Singh (2007). A checklist of butterflies of Madhya Pradesh and Chattisgarh states, India. Zoos' Print Journal 22(8): 2790-2798.

Chandrakar, M., S. Palekar \& S. Chandkar (2007). Butterfly fauna of Melghat region, Maharashtra. Zoos' Print Journal 22(7): 2762-2764.

Devy, M.S. \& D. Priya (2001). Response of wet forest butterflies to selective logging in Kalakad-Mundanthurai Tiger Reserve: Implications for conservation. Current Science 80(3): 400-405.

Didham, R.K. \& N.D. Springate (2003). Determinants of temporal variation in community structure. pp. 28-39 In: Basset, Y., V. Novotny, S.E. Miller \& R.L. Kitching (eds.). Arthropods of Tropical Forests. Spatio-temporal Dynamics and Resource Use in the Canopy. Cambridge University Press, Cambridge.

Dolia, J., M.S. Devy, N.A. Aravind \& A. Kumar (2008). Adult butterfly communities in coffee plantations around a protected area in the Western Ghats, India. Animal Conservation 11: 26-34.

Erhardt, A. (1985). Diurnal Lepidoptera: sensitive indicators 
of cultivated and abandoned grassland. Journal of Applied Ecology 22: 849-862.

Eswaran, R. \& P. Pramod (2005). Structure of butterfly community of Anaikatty hills, Western Ghats. Zoos' Print Journal 20(8): 1939-1942.

Gajendiran, N. \& S. Ragupathy (2002). The macroflora of east coast at Kalpakkam. Report submitted to Director IGCAR. Kalpakkam.

Gilbert, L.E. \& M.C. Singer (1975). Butterfly ecology. Annual Review in Ecological Systematics 6: 365-397.

Gunathilagaraj, K., T.N.A. Perumal, K. Jayaram \& M.G. Kumar (1998). Some South Indian Butterflies: Field Guide. Project Lifescape, Indian Academy of Science, Bangalore, 274pp.

Hill, J.K., K.C. Hamer, M. Dawood, J. Tangah \& V.K. Chey (2003). Interactive effects of rainfall and selective logging on a tropical forest butterfly in Sabah, Borneo. Journal of Tropical Ecology 19: 1-8.

Hussain, K.J., K.K. Satpathy, M.V.R. Prasad, V.T. Sridharan, T. Ramesh \& M. Selvanayagam (2008). Faunal Diversity Assessment at Department of Atomic Energy (DAE) Campus, Kalpakkam. IGCAR 268pp.

Joshi, P.C. (2007). Community structure and habitat selection of butterflies in Rajaji National Park, a moist deciduous forest in Uttaranchal, India. Tropical Ecology 48(1): 119123.

Kitahara, M., K. Sei \& K. Fujii (2000). Patterns in the structure of grassland butterfly communities along a gradient of human disturbance: further analysis based on the generalist/ specielist concept. Population Ecology 42: 135-144.

Koh, L.P. \& N.S. Sodhi (2004). Importance of reserves, fragments and parks for butterfly conservation in a tropical urban landscape. Ecological Applications 14: 1695-1708.

Kremen, C. (1992). Assessing the indicator properties of species assemblages for natural areas monitoring. Ecological Applications 2: 203-217.

Krishnakumar, N., A. Kumaraguru, K. Thiyagesan \& S. Asokan (2008). Diversity of papililonid butterflies in the Indira Gandhi wildlife sanctuary, Western Ghats, southern India. Tiger Paper 35: 1-8.

Kumar, M.P.M.P., B.B. Hosetti, H.C. Poomesha \& H.T.R. Gowda (2007). Butterflies of the Tiger Lion Safari, Thyavarekoppa, Shimoga, Karnataka. Zoos' Print Journal 22(8): 2805.

Kunte, K. (1997). Seasonal patterns in butterfly abundance and species diversity in four tropical habitats in the northern Western Ghats. Journal of Bioscience 22: 593-603.

Kunte, K. (2000). Butterflies of Peninsular India. Universities Press Limited, Hyderabad, India, 254pp.

Kunte, K. (2000-01). Butterfly diversity of Pune city along the human impact gradient. Journal of Ecological Society 13\&14: 40-45.

Kunte, K. (2005). Species composition, sex-ratios and movement patterns in Danaine butterfly migrations in southern India. Journal of the Bombay Natural History Society 102(3): 280-286.
McAleece, N., P.J.D, Lambshead \& P.L.J. Paterson (1997). BiodiversityPro (Version 2). The Natural History Museum, London.

Mathew, G. \& M. Anto (2007). In situ conservation of butterflies through establishment of butterfly gardens: A case study at Peechi, Kerala, India. Current Science 93(3): 337-347.

Nair, V.P. (2002). Butterflies of the Government College campus, Madappally, Kozhikode District, Kerala. Zoos' Print Journal 17(10): 911-912.

Padhye A.D., N. Dahanukar, M. Paingankar, M. Deshpande \& D. Deshpande (2006). Season and landscape wise distribution of butterflies in Tamhini, northern Western Ghats, India. Zoos' Print Journal 21(3): 2175-2181.

Palot, M.J. \& V.P. Soniya (2003). A preliminary report on the butterflies of Lonar Crater Lake, Buldhana District, Maharashtra. Zoos' Print Journal 18(11): 1267-1268.

Pollard, E. (1991). Monitoring butterfly numbers: p. 87. In: Goldsmith, F.B. (ed.). Monitoring for Conservation and Ecology, Chapman and Hall, London.

Rane, N.S \& S.P. Ranade (2004). Butterflies of Tamhini Dongarwadi area, Mulshi, Maharashtra. Zoos 'Print Journal 19(3): 1411-1413.

Roy, D.B., P. Rothery, D. Moss, E. Pollard \& J.A. Thomas (2001). Butterfly numbers and weather: predicting historical trends in abundance and the future effects of climate change. Journal of Animal Ecology 70: 201-217.

Rufus, K.C. \& S.P. Sabarinathan (2007). A checklist of butterflies of Thengumarahada in the Nilgiris, southern India. Zoos' Print Journal 22(9): 2837-2838.

Shanthi, R., K.J. Hussain \& K.P. Sanjayan (2009). Influence of weather on the incidence of sucking pest complex on summer-irrigated cotton crops of Tamil Nadu. Hexapoda 16(1): 89-92.

Soniya, V.P. \& M.J. Palot (2002). On a collection of butterflies from paddy field ecosystem of Palakkad District, Kerala. Zoos' Print Journal 17(7): 829.

Southwood, T.R.E.(1975). The dynamics of insect populations. pp. 151-199. In: Pimentel, D. (ed.). Insects, Science, and Society. Academic Press, New York.

Sreekumar, P.G. \& M. Balakrishnan (2001). Habitat and altitude preferences of butterflies in Aralam Wildlife Sanctuary, Kerala. Tropical Ecology 42(2): 277-281.

Swaay, C.A.M (1990). An Assessment of the Changes in Butterfly Abundance in The Netherlands during the $20^{\text {th }}$ Century. Biological Conservation 52: 287-302

Tiple, A.D., V.P. Deshmukh \& R.L.H. Dennis (2006). Factors influencing nectar plant resource visits by butterflies on a university campus: implications for conservation. Nota Lepidopterologica 28: 213-224.

Tiple, A.D., A.M. Khurad \& R.L.H. Dennis (2007). Butterfly diversity in relation to a human-impact gradient on an Indian university campus. Nota Lepidopterologica 30(1): 179-188.

Tiple, A.D. \& A.M. Khurad (2009). Butterfly Species Diversity, Habitats and Seasonal Distribution in and around 
Nagpur City, Central India. World Journal of Zoology 4(3): 153-162

Walpole, M.J. \& I.R. Sheldon (1999). Sampling butterflies in tropical rainforest: an evaluation of a transect walk method. Biological Conservation 87: 85-91.

Williams, C.B. (1927). A study of butterfly migration in south India and Ceylon, based largely on records by Mssrs. G. Evershed, E.E. Green, J.C.F. Fryer and W. Ormiston. Transactions of the Entomological Society of London 75: 1-33.

Williams, C.B. (1930). The Migration of Butterflies. Oliver and Boyd, Edinburgh, London, 473pp.

Williams, C.B. (1938). The migration of butterflies in India. Journal of the Bombay Natural History Society 40: 439-457.

Woods, J.N., J. Wilson \& J.R. Runkle (2008). Influence of Climate on Butterfly Community and Population Dynamics in Western Ohio. Environmental Entomology 37(3): 696-706.
Author Details: DR. K. JAHIR HuSSAIN has obtained his MSc and MPhil in Zoology from Madurai Kamaraj University and $\mathrm{PhD}$ from the University of Madras in the year 2007. He has published a book on Biodiversity of DAE campus, Kalpakkam. He is presently working on biodiversity conservation and environmental impact assessment in IGCAR and designated as visiting scientist. SHRI. T. RAMESH is a research scholar since 2008, after successfully completing his M.Sc and M.Phil in Zoology from Madura Kamaraj University. He has enrolled for PhD under the guidance of Dr. M. Selvanayagam. DR. K.K. SATPATHY is an environmental scientist with several papers and books to his credit. Presently he is head, Environmental and Safety Division and Chairman, Environmental Empowered Task Force of IGCAR. PROF. M SelvanAYAgam is a well known zoologist from Loyola College, Chennai and he is the director of Loyola Institute of Frontier Energy. 